\title{
Creation of Borer Pests Resistance Genetically Engineering Peach (Prunus Persica L.) Plants by Cloning cry1Ab Gene
}

\section{NAIF MOHAMED KADASA}

Jeddah University: University of Jeddah

Ehab Mohamed Rabei Metwali ( $\nabla$ ehabmetwali@hotmail.com )

Suez Canal University Faculty of Agriculture

Hemaid Ibrahim Soliman

DRC: Desert Research Center

Wafa Alshehri

University of Jeddah

\section{Research Article}

Keywords: Peach (Prunus persica L.), Agrobaterium, Gene expression, Synthetic cry1Ab gene, Insect bioassay

Posted Date: July 20th, 2021

DOl: https://doi.org/10.21203/rs.3.rs-703653/v1

License: (9) This work is licensed under a Creative Commons Attribution 4.0 International License. Read Full License 


\section{Abstract}

The plasmid pBI121 cry $1 \mathrm{Ab}$ was used to transform peach explants to produce insect resistant plants. The plasmid was constructed from cloning the synthetic crylAb gene with intron of castor bean catalase-1 gene into the pBI121 binary vector under the control of CaMV35S promoter. Leaf discs of peach (Prunus Persica L.) were co-cultivated for two days with A. tumefaciens strain LBA 4404. Explants were plated on WPM medium supplemented with $125 \mathrm{mg} / \mathrm{l}$ kanamycin, $3 \%$ sucrose, $2.5 \mathrm{mg} \mathrm{L}^{-1}$ 2,4-D (2,4Dichlorophenoxyacetic acid) and $0.5 \mathrm{mg} / \mathrm{l} \mathrm{BA}$ (6-benzyladenine) in darkness for callus formation. The calli were then selected on WPM medium supplemented with $125 \mathrm{mg} \mathrm{L}^{-1}$ kanamycin, $3 \%$ sucrose, 3.00 mg L-1 TDZ (Thidiazuron), $1.0 \mathrm{mg} \mathrm{L}-1 \mathrm{Kn}$ (kinetin) and $0.5 \mathrm{mg} \mathrm{L}-1 \mathrm{IAA}$ (Indoleacetic acid) in the light for at least five subcultures (with a regeneration efficiency of $91.8 \%$ ). The integration of crylAb gene into the peach genome was confirmed by PCR (polymerase chain reaction) and northern blot analysis. The transformation efficiency (28\%) was obtained when leaves were incubated for $15 \mathrm{~min}$. with $A$. tumefaciens. The crylAb gene expression was confirmed using RT-PCR, northern blot hybridization, immune-strip test and insect bioassays, respectively. For insect bioassay, it was evident from data the toxin CrylAb protein expressed in transformed peach plants showed $100 \%$ mortality at $1000 \mathrm{ppm}$ against Synanthedon exitiosa larvae's after $96 \mathrm{hr}$. These results obtained improved significantly of CrylAb toxin protein against lepidopteron larvae of peach.

\section{Key Message}

In vitro peach regeneration from in vitro leaves is difficult, as well as regeneration using the method of genetic transfer such as agrobacterium to impart the desired characteristics of the plants with the aim of improvement is very difficult. This paper is the first to transgenic peach plants carrying cry $1 \mathrm{Ab}$ gene for insect resistance particularly the peach tree borer.

\section{Introduction}

Peach (Prunus persica) is a deciduous tree or shrub reaching up to 8-9 meters in height, have the ability to produce fruit for 20 years, believed to have originated in China and considered the eighth most main commercial fruit crop worldwide (Souza et al. 2011). The peach belong to the Rosaceae family, which has many other species of commercial importance, contains many fruit, nut, and ornamental species (Wang et al. 2002; Bodh et al. 2019). The Mediterranean region is the center of world production, especially in Italy, Spain, France and Turkey (Declerck and Korban 1996; Gentile et al. 2002). The percentage of areas planted with peaches in terms of the size is distributed as follows: $71.8 \%$ Asia, $16.4 \%$ Europe, 15\% China, 7.4\% Americas and 4.1\% Africa, but in the last 4 years, the area planted with peaches decreased from $1600 \mathrm{k}$ ha in a year 2015 to $1500 \mathrm{~K}$ ha in a year 2019 (FAO 2020) http://www.fao.org/faostat/en/\#data/QC/visualize.

Peach trees are exposed to many different pests and diseases such as peach tree borer (Synanthedon exitiosa), the yellow peach moth (Conogethes punctiferalis), the cutworm moths (Abagrotis 
orbis), Lyonetia prunifoliella, the fruit tree borer (Maroga melanostigma), which causes strike serious damage of trees and fruits which reducing production and quality (Zehr et al. 1995; Cottrel et al. 2006; CABI 2014). Insect herbivores cause huge losses in crop production, reducing yields in major crops by up to $20 \%$ (Ferry et al. 2004). The peach tree borer, Synanthedon exitiosa (Say) (Lepidoptera: Sesiidae), is a very dangerous agriculture pest that infects a variety of stone-fruit trees such Prunus spp. including peach (Prunus persica L.), is responsible for more damage to peach trees than all other insect pests (Johnson et al. 2005). S exitiosa do not attack the fruit, but rather the tree itself, hiding in its trunk near ground level or blowing into it and devouring the live cambium layer of the trunk and large roots that form arcades located around the surface of the soil to a depth of approximately $30 \mathrm{~cm}$. (Shapiro-llan et al. 2015). Also, Reilly et al. (1987) mention to the peach tree borer can damage the tree by inducing plant pathogens to invade the weakened tree. Countries around the world spend more than $\$ 3$ billion each year to reduce insect pests (Wilcox et al. 1986). Sales microbial insecticide are estimated to be less than $1 \%$ of this total but are expected to increase by up to $70 \%$ by year 2020 (Tabashnik et al. 1990). Numerous studies have indicated the effectiveness of using microbiological control agents as a biological therapeutic method to manage insect pests in agriculture ecosystems (Shapiro-llan et al. 2009; El-Gaied et al. 2020). One of these biological insecticides organisms is $B$. thuringiensis (Bt) which used to control Spodoptera exigua (Hübner; Lepidoptera: Noctuidae)-a worldwide, polyphagous pest species (Baranek et al. 2020). Bt is notable for its production of a variety of insecticidal crystalline proteins that are encoded by cry genes (Höfte and Whiteley 1989; Atia 2020). Cry proteins is safe alternative to chemical pesticides, not toxic to humans, and it does not cause the serious environmental (Balaraman 2005). With this base of knowledge on $B t$ and cry protein the possibility are open to apply several strategies such as using cry protein by genetic engineering to improve pest control and reduce pesticides (Jenkins and Dean 2000). The use of protein engineering has become an interesting topic, due to the significant public debate that exists regarding its potential benefits or adverse effects (Kranthi and Stone 2020).

Modified crops containing cry genes that express sufficient levels of insecticidal proteins have been developed to protect them from attacks insect pests in many plants (Betz et al. 2000; Ranjekar et al. 2003). As a result of the expansion in the cultivation of these GMC on a large commercial scale, this can generate mutation in target insect pests, as has happened with chemical insecticides, Consequently, the potential development of insect resistance is the greatest threat to breeding programs for the sustainable use of modified plants (Shelton et al. 2002; Butko 2013). Accordingly, working on developing genetic engineering techniques will remain the most important duty of plant breeders to sustain the fight against insect diseases. Several reports are available on dicot and monocot species that have been transformed using these genes and become resistant to insect pests using biotechnology tools (Hinchee et al. 1988; Perlak et al. 1993; Nayak et al. 1997; Gomez et al. 2014). There are several genetically modified crops with the Bt cry $1 A b$ gene that have been to be highly effective against larval insect pests (Ye et al. 2001; Dutton et al. 2005; Pardo et al. 2013; Hemaid et al. 2017; Xu et al. 2018).

Prunus species is one of the most difficult species of perennial trees to produce in vitro regeneration shoots, although reports have obtained of successful in vitro regeneration and transformation species recently (Gentile et al. 2003; Song and Sink 2005; Petri et al. 2008; Zhou et al. 2010; Sidorova et al. 
2017and 2019; Sabbadini et al. 2019; Ricci et al. 2020). In vitro shoot regeneration of peach from juvenile or seedling explants is achieved, but is difficult to accomplish from mature plant (San et al. 2014). Nevertheless, adding more desirable characteristics while preserving valuable traits of mature genotypes requires reliable and good tools for regeneration and genetic transformation (Zhou et al. 2010).

This work describes the transformation of peach (Prunus persica L.) by using Agrobacterium tumefaciens having $c r y 1 A b$ gene to improve of insect resistant peach and evaluation of $c r y 1 A b$ gene expression in peach plant against Synanthedon exitiosa. This is the first report of the synthesis and expression of $C r y 1 A b$ gene in putative transgenic peach plants.

\section{Materials And Methods}

\section{Construction of the synthetic $c r y \mid A b$ gene and bacterial strain.}

The cry1Ab gene under the control of the CaMV35S promoter and kanamycin resistance gene (npt-II) as a plant selectable marker under the NOS promoter were sub-cloned in the binary plasmid vector pBI121, designated as pBI121 cry1Ab has a 1845 bp fragment of the cry1 Ab gene containing the intron of castor bean catalase-1 gene (190 bp) with a pair of synthetic linkers of BamHI site and the terminator of nopaline synthase gene (Fig.1). The cry1 Ab gene has been cloned and their nucleotide sequence was determined from Bacillus thuringiensis. The plasmid pBI121 cry1Ab was constructed by Prof. Dr. Hemaid I.A. Soliman from cloning the synthetic cry1Ab gene. The plasmid pBI121 cry1Ab were transformed into the $A$. tumefaciens strain LBA4404 and used for peach (Prunus Persica L.) transformation experiments.

\section{In vitro regeneration of peach (Prunus Persica L.)}

Leaves collected after on month from in vitro proliferating microshoots of peach (Prunus Persica L.) cv. Balady grown in Taif governorate, Saudi Arabia previously propagated by stem nodal sections on MS medium containing $2 \mathrm{mg} \mathrm{L-1}$ Benzyle adenine (BA), $0.2 \mathrm{mg} \mathrm{L}-1$ indole3 butyric acid (IBA), $30 \mathrm{~g} \mathrm{I-}$ 1sucrose and $2.5 \mathrm{~g} \mathrm{l}-1$ phytagel as described by Soliman (2013). The MS medium was adjusted for $\mathrm{pH}$ 5.8 and was autoclaved for $20 \mathrm{~min}$ at $121^{\circ} \mathrm{C}$. All samples were incubated at $25 \pm 2{ }^{\circ} \mathrm{C}$ with a light period of $16 \mathrm{hrs}\left(3240 \mu \mathrm{mol} \mathrm{m} \mathrm{s}^{-1}\right.$ intensity). The in vitro leaves were cut (5 mm length) and planted on two different media: MS (Murashig and Skoog 1962) and WPM (Lloyd and McCown 1980) containing different concentrations of 0.5 - $4.0 \mathrm{mg} \mathrm{L-1}$ 2,4-D in combination with 0.25 - $3.0 \mathrm{mg} \mathrm{L-1} \mathrm{BAP} \mathrm{or} \mathrm{kinetin.}$ The samples were incubated in growth room at $25 \pm 2^{\circ} \mathrm{C}$ in the dark for callus induction. For in vitro adventitious shoot regeneration, the calli were transferred to two media (MS and WPM) containing 5.0 $\mathrm{mg} \mathrm{L-1} \mathrm{TDZ} \mathrm{alone} \mathrm{or} \mathrm{in} \mathrm{combination} \mathrm{with} \mathrm{1.0-3.0} \mathrm{mg} \mathrm{L-1} \mathrm{kinetin,} \mathrm{0.5-2.0} \mathrm{mg} \mathrm{L-1} \mathrm{BAP} \mathrm{and} \mathrm{0.25-1.0} \mathrm{mg} \mathrm{L-1}$ IAA at 4 weeks under the light intensity of $60-70 \mu \mathrm{mol} \mathrm{m} \mathrm{s}^{-1}$ for shoot induction. 
For shoot elongation, adventitious microshoots of regenerated peach from previously step were cultured on MS medium supplemented with $0.5 \mathrm{mg} \mathrm{L-1} 2 \mathrm{iP}$ for 4 weeks and then elongated shoots were transferred to MS liquid medium supplemented with $2.0 \mathrm{mg} \mathrm{L}-1$ IBA , $0.5 \mathrm{mg} \mathrm{L}-1$ NAA and $162 \mathrm{mg} \mathrm{L-1}$ phloroglucinol. The shoots were incubated at $26 \pm 2^{\circ} \mathrm{C}$ in complete dark for one week and then transferred into light condition for three weeks for rooting formation as described by Soliman (2013) and Ricci et al. (2020). For acclimatization, the next applied process was taken according to Metwali et al. (2015); the plants were acclimatized by transferring them to pots containing a mixture of autoclaved peatmoss and sand (3:1), then the pots covered with plastic bags and placed in the growth chamber at $28 \pm 2^{\circ} \mathrm{C}$ and 16 hour light period. After 10 days the plants were hardened by plastic cover removed gradually over a 710 day-period.

\section{Kanamycin sensitivity test}

Determining the appropriate kanamycin concentration is very important in the selection of transformed plants by inhibiting non-transformed plants growth (Colby and Meredith 1990). Kanamycin was prepared by filtration through filters $(0.22 \mu \mathrm{n})$ and placed into medium when in pre-cooled $\left(45-50^{\circ} \mathrm{C}\right)$. The leaf segments were planted on callus WPM medium supplemented with 25- $150 \mathrm{mg} \mathrm{L-1}$

Kanamycin. Subculture was applied every two weeks onto fresh callus WPM medium under the same composition. The survival explants (kanamycin resistant) percentage was tested after four weeks.

\section{Agrobacterium Transformation}

To prepare the bacteria for use in the process of transformation, Agrobactrium tumefaciens strain (LBA4404) harboring the binary vector plasmid pBI121 cry1Ab containing the synthetic crylAb gene and npt-II gene was cultured in LB liquid medium containing both rifampicllin and kanamycin at a concentration of $50 \mathrm{mg} \mathrm{L}-1 \mathrm{mg} \mathrm{L}-1$ at $28^{\circ} \mathrm{C}$ for overnight (Sambrook et al. 1989) and then Agrobacterium suspension culture was mixed to $50 \mathrm{ml}$ WPM medium free hormones and incubated at $28^{\circ} \mathrm{C}$ until optical density at $600 \mathrm{~nm}(0 \mathrm{D} 600 \mathrm{~nm})$ - using spectrophotometers (Unicam5625 UV/Vis Spectrophotometer, United Kingdom) - reaches the limit between 0.5-1.0 as an indication of Log phase. Leaf explants were cut into the bacterial solution and left for $15 \mathrm{~min}$. Excess bacterial solution was eliminated by placing the leaf segments on the sterile filter papers, then the inoculated were transferred to solidified WPM medium containing 2,4-D at $2.5 \mathrm{mg} \mathrm{L-1}$ and BA at $0.5 \mathrm{mg} \mathrm{L}-1$ and incubated for 2 days in the dark at $28 \pm 2^{\circ} \mathrm{C}$. After co-cultivation, the leaf segments were cultured on callus WPM medium supplemented $250 \mathrm{mg} \mathrm{L}-1$ cefotaxime and $125 \mathrm{mg} \mathrm{L}-1$ knamycin for one month at $26 \pm 2^{\circ} \mathrm{C}$ in the dark and then transferred to regenerated WPM medium supplemented with the same antibiotics and incubated at $26 \pm 2^{\circ} \mathrm{C}$ under $16 \mathrm{~h}$ light period $(60-70 \mu \mathrm{mol} \mathrm{m} 2 \mathrm{~s} 1)$.

\section{DNA isolation and molecular analyses}


DNA transgenic leaf peach was isolated and the presence of the cry $1 A b$ gene was determined with gene specific primers using PCR (Applied Biosystems ${ }^{\text {TM }}$ Cat. No; A24811; Thermo Fisher Scientific, Inc., Waltham, MA, USA). For cry $1 A b$, two primers, F: 5'- GTTACCCTGATTGATAGGC-3' cry1Ab R: 5'ACAGAAGACCTTTCAATATC-3' was made to amplify the $2035 \mathrm{bp}$ fragment of the crylAb gene by PCR using a volume of $50 \mu \mathrm{l}$ for a final concentration containing $2 \mathrm{ng}$ of plant DNA (as template), 1 pmoles of each of the primers used, $200 \mu \mathrm{M}$ of dNTPs , $0.04 \mathrm{U}$ Taq DNA polymerase, $2.5 \mathrm{mM} \mathrm{MgCl}$, $1 \mathrm{X}$ PCR buffer and complete the volume dH2O according to manufacturer's instructions (Sigma, USA). Single step PCR is performed at $95^{\circ} \mathrm{C} / 5 \mathrm{~min}$. The PCR reaction consisted of a single step of $95^{\circ} \mathrm{C}$ for $5 \mathrm{~min}$., followed by 35 cycles at $94^{\circ} \mathrm{C} / 1 \mathrm{~min} ., 57^{\circ} \mathrm{C} / 1 \mathrm{~min} ., 72^{\circ} \mathrm{C} / 2 \mathrm{~min}$., and a final extension at $72^{\circ} \mathrm{C} / 8 \mathrm{~min} .15$ $\mu \mathrm{l}$ of PCR reaction mixture with $3 \mu$ l loading buffer was loaded onto a $1 \%$ agarose gel and run at 80 Volt.

\section{RT-PCR and Northern blot hybridization}

Total RNA from peach leaves by phenol/chloro-form procedure (Sambrook et al. 1989) was separated on $1.2 \%$ on formaldehyde gel and then transferred to a nylon $\mathrm{N}+$ membrane (Amersham) according to the manufacturer's instructions QIAGEN. Membranes were hybridized with 32P dCTP-labelled BamHI (2035bp) fragment of the $c r y l A(b)$ gene as probe overnight at $42^{\circ} \mathrm{C}$. The same $c r y 1 A b$ primer set for PCR reactions was also used for the RT-PCR. The RT-PCR reaction was set according to technical bulletin provided with "Access RT-PCR" kit Agdia protocol (Agdia Inc., Elkhart, IN, USA). The amplification conditions protocol are 30 cycles of $94^{\circ} \mathrm{C} / 2 \mathrm{~min}$., $65^{\circ} \mathrm{C} / 30 \mathrm{~s}, 72^{\circ} \mathrm{C} / 2 \mathrm{~min}$., and the final reaction at $72^{\circ} \mathrm{C} /$ 5 min. RT-PCR products were shown in a $1 \%$ agarose gel by electrophoresis.

\section{Survey with Trip Tests for the Cry1Ab protein}

The leaves of transgenic peach plants which positive cry $1 \mathrm{Ab}$ gene confirmed by PCR analysis were assayed to detect the expression of Cry $1 \mathrm{Ab}$ protein using Immuno Strip ${ }^{\circledR} \quad$ (Immuno Strip ${ }^{\circledR}$ has two test lines; one for the Bt-Cry2A and one for the Bt-Cry1Ab/Ac protein, Agdia Inc.,USA) from Agdia following the procedure given by (Agdia 2003) and the according to the manufacturer's instruction Agdia protocol (Agdia Inc., Elkhart, IN, USA). The leaves were ground with a rotary pestle and added $0.5 \mathrm{ml}$ extract buffer was mixed with the leaf powder. QuickStix strips were incubated with leaf extraction buffer. After ten minutes the reaction results were checked and were examined the bands on the strip.

\section{Bioassay for insect toxicity}

Bioassay of transformed peach (Prunus persica L.) plants with the Synanthedon exitiosa (peach tree borer) larvae's was used to confirm the Cry1ab protein expression in positive transformed peach plants. Synanthedon exitiosa (peach tree borer) larvae's that had been collected from infested peach orchard during July 2020 according to procedures described by Cottrell and Shapiro-llan ( 2006). When dissolving $0.1 \mathrm{gm}$ of transformed dried peach leaves in $100 \mathrm{ml}$ of water gives $1000 \mathrm{ppm}$, and then different concentrations from stock concentration (200-1000 ppm) were prepared. To each cup containing artificial media with $500 \mu \mathrm{l}$ of each dilution was added and three replicates were prepared from each experiment. 10 neonate larvae were incubated on the surface of the medium after the surface 
of the solution was completely dry and cups were covered with aluminum foil and left at $26^{\circ} \mathrm{C}\left( \pm 2^{\circ} \mathrm{C}\right)$. On the other hand, negative control medium was prepared exactly as mentioned above but the toxin replace with an addition $500 \mu \mathrm{l} \mathrm{H2O}$. Data were taken and mortality was calculated every day for five days.

\section{Statistical analysis}

Statistical analysis of all experiments data was performed as a completely randomized design with three replicates. The recorded data were analyzed statistically using the analysis of variance technique (ANOVA) and by multiple range tests (Steel et al. 1997). The means significance was compared by applying the (L.S.D.) test at $5 \%$ level of probability.

\section{Results And Discussion}

\section{Callus induction and plantlet regeneration of peach (Prunus Persica L.)}

In the current study leaf explants of peach (Prunus persica L.) induced callus on both of two different media: MS and WPM supplemented with different concentrations of 0.5-4.0 mg L-1 2,4-D in combination with $0.25-3.0 \mathrm{mg} \mathrm{L-1}$ BAP or kinetin as shown in Table (1). The results showed that, the highest \% of explants formed callus ( $89.5 \% ; 87.8 \%$ ) and the highest callus fresh weight was $(3.78 \mathrm{~g} ; 3.68$ g) was recorded on $2.5 \mathrm{mg} \mathrm{L}-1$ 2,4-D with $0.5 \mathrm{mg} \mathrm{L}-1$ BAP followed by $3.0 \mathrm{mg} \mathrm{L-1}$ 2,4-D with $1.0 \mathrm{mg} \mathrm{L-}$ $1 \mathrm{BAP}$, respectively on WPM medium compared to MS medium at the same concentration of PGR. Although $2.5 \mathrm{mg} \mathrm{L-1}$ 2,4-D with $0.5 \mathrm{mg} \mathrm{L-1} \mathrm{BAP} \mathrm{on} \mathrm{WPM} \mathrm{medium} \mathrm{recorded} \mathrm{the} \mathrm{best} \mathrm{treatment} \mathrm{of} \mathrm{\%}$ explants formed callus and callus fresh weight, but on MS medium the best values for the both previous traits $(84.9 \% ; 3.55 \mathrm{~g})$ were recorded at concentration $3.0 \mathrm{mg} \mathrm{L}-1$ 2,4-D with $1.0 \mathrm{mg} \mathrm{L}-1$ BAP. This result is in agreement with Declerck and Korban (1996) and Pérez-Jiménez et al. (2013). Compared to other auxins, hypotheses developed to explain the positive action of 2, 4-D that could be due to inhibition of the DRT102 protein, which is responsible for stimulating cell division, DNA replication and lead to decrease in the number of cells (Pasternak et al. 2002). Moreover, in previous study of (Zuo et al. 2002), he explained the effect of the hormone 2,4-D as a signal trigged to alert the beginning of hyperpolarization process of membrane polypeptides in in the cell .. Reis et al. (2021) recently mentioned that the growth of callus effectively in the artificial media is linked to 2,4-D hormone homeostasis, which directly effects on the efficient accumulation of storage reserves of callus. On the other hand, the effect of the exogenously applied of 2,4-D and BA may be due to its stimulus to increase the endogenous levels of IAA, which is known to be an activator of cell division and differentiation, especially under dark incubation or low light intensity Migual et al. (1996).

The callus obtained from in vitro leaf was transferred to the regeneration media containing 1.0-5.0 mg L-1 TDZ alone or in combination with 1.0-3.0 mg L-1 kinetin, 0.5-2.0 mg L-1 BAP and 0.25-1.0 mg L-1 IAA. Observation of regeneration efficiency was recorded from callus as shown in Table (2). The result showed that, the highest \% of callus formed shoots $(91.8 \% ; 88.5 \%)$, number of adventitious buds/callus (8.75 ; $7.25)$ and mean shoot length $(3.87 \mathrm{~cm} ; 3.70 \mathrm{~cm})$ was showed on WPM medium MS medium respectively 
supplemented with $3.00 \mathrm{mg} \mathrm{L}-1 \mathrm{TDZ}, 1.0 \mathrm{mg} \mathrm{L}-1$ kinetin and $0.5 \mathrm{mg} \mathrm{L}-1$ IAA. The results indicated that the WPM medium was better than MS medium and the TDZ succeeded in being effective in the case of using with IAA. The results of the present study are in agreement with Pérez-Jiménez et al. (2013) who reported that the best results for regeneration percentages and proliferation of the shoot were obtained with thidiazuron (TDZ) instead of 6-benzylamino-purine (BAP) and TDZ is considered one of the best growth regulators to obtain large number of plantlets and shoot induction of callus comparing with other growth regulators such as BA. Also, previous study indicated the efficiency of TDZ to enhance Agrobacterium-mediated transformation in Prunus Persica (Soliman 2013). This availability of the efficient plant regeneration from different meristem tissues is a prerequest to improve peach species via gene transfer technology (Ricci et al. 2020).

Effect of kanamycin on explant regeneration

Kanamycin is the most suitable selective antibiotic for transformed tissues in most of the plant species (Oropeza-Aburto et al. 2020). To determine the optimum concentration of the lethal dose of kanamycin in peach, different concentrations of kanamycin ranged from 25 up to $150 \mathrm{mg} \mathrm{L}-1$ were applied plus the control. The high rate of survival ( $100 \%)$ for leaf segment explants was obtained under kanamycin free medium. On the contrary, under the medium treated with kanamycin, the survival rate was lower as the concentration of the kanamycin increased in the medium. Leaf segments rate of survival has reached to $18 \%$ under of $100 \mathrm{mg} \mathrm{L}-1$ kanamycin, while the lethal kanamycin dose for the survival was assessed at $125 \mathrm{mg} \mathrm{L}-1$ kanamycin (Fig. 2). The concentration of $125 \mathrm{mg} \mathrm{L}^{-1}$ kanamycin was then chosen as a selection marker for transformed tissues in peach, where Cosson et al. (2015) indicated that the selection agent should be able to completely inhibit the growth of non-transgenic plant cells, and it is desirable that the lowest concentration that can achieve this must determined. But in different species such as grapevine, vitis and cotton the optimum concentration of kanamycin for selection was 50,70 and $75 \mathrm{mg}$ $\mathrm{L}^{-1}$, respectively (Dhekney et al. 2006; Sabbadini et al. 2019; Zhang et al. 2001). This variation in kanamycin concentration may be due to the difference in genotypes as well as the type of explant (Abbosi et al. 2020). Also, previous reports demonstrated that development stage of explant may be an influencing factor in determining the concentration of kanamycin and accordingly the selection concentration should be changed along with development of culture (Zhang et al. 2001).

\section{Transformation of peach (Prunus Persica L.)}

Leaf section explants were collected from one month-old in vitro peach (Prunus persica L.) plants and used as explants (Fig. 3a). Explants were suspended in A. tumefaciens LBA4404 for 15 minutes as described in material and methods section. Results showed that kanamycin resistant callus formation (21\%) was obtained on WPM medium containing $30 \mathrm{~g} \mathrm{~L}^{-1}$ sucrose, $2.5 \mathrm{mg} \mathrm{L}-1$ 2,4-D and $0.5 \mathrm{mg} \mathrm{L}-1$ BAP, $250 \mathrm{mg} \mathrm{L}-1$ cefotaxime and $125 \mathrm{mg} \mathrm{L}-1$ kanamycin compared to the control (89.5\%) after one month at $26 \pm 2^{\circ} \mathrm{C}$ in the dark (Fig. $3 \mathrm{~b}-\mathrm{C}$ ). Also Kanamycin resistant calluses cultured onto regenerated solidified WPM medium supplemented with $30 \mathrm{~g} \mathrm{L-1}$ sucrose, $3.0 \mathrm{mg} \mathrm{L-1}$ TDZ, $1.0 \mathrm{mg} \mathrm{L-1}$ kinetin, $0.5 \mathrm{mg} \mathrm{L-1}$ IAA and $125 \mathrm{mg} \mathrm{L-1}$ Kanamycin succeeded to obtained shoot regeneration (79\%) after incubated for six 
weeks at $26 \pm 2^{\circ} \mathrm{C}$ under an $8 / 16 \mathrm{~h}$ (light/dark) photoperiod $\left(60-70 \mu \mathrm{mol} \mathrm{m} \mathrm{m}^{2}\right)$ as shown in the Fig. ( $3 \mathrm{~d}$-ef). Putative transformed adventitious microshoots was elongated on medium containing $0.5 \mathrm{mg} \mathrm{L}-1$ 2iP after one month (Fig. 4a) and started to forming root using MS liquid medium supplemented with $100 \mathrm{mg}$ L-1 myo-inositol, $30 \mathrm{~g} \mathrm{~L}-1$ sucrose, $2.0 \mathrm{mg} \mathrm{L}-1$ IBA and $0.5 \mathrm{mg} \mathrm{L}-1 \mathrm{NAA}$ and $162 \mathrm{mg} \mathrm{L}^{-1}$ phloroglucinol at $26 \pm 2^{\circ} \mathrm{C}$ in complete dark for one week and then transferred into light condition for three weeks (Fig. 4 bC). Acclimation protocol was successfully achieved highest percentage of survival transgenic peach plants (91\%) as described by Soliman (2013) (Fig. 4d). Recently study proposed that the ability of explants from woody fruit species to regenerate shoots and efficiency protocols for Agrobacteriummediated transformation remains a major impediment to genetic modification and gene editing technologies (Song et al. 2019; Orbović 2019).

PCR detection of transformed peach plants

Transformed peach plants were screened for the presence of the cry $1 A b$ gene using PCR analysis with cry $1 A b$ gene specific primers. The expected 2035 bp cry $1 A b$ fragment was amplified only from genomic DNA isolated from the kanamycin resistant peach plants compared to nontransformed peach plants. The PCR has the potential to become a widespread tool to confirm the presence of a foreign gene such as Vis1 in tomato (Metwali et al. 2015), GmbZIP2 in soybean (Yang et al. 2020) and PpMYB10.1 in peach (Xu et al. 2020) in transgenic plant tissues. In the current study out of 60 plants examined from kanamycin resistant peach regenerated plants only 17 gave positive results. This indicated the success of the process of transferring the cry $1 \mathrm{Ab}$ gene through Agrobacterium-mediated transformation method with the rate of $28 \%$ as putative transgenic peach plants (Fig. 5). That rate of obtaining genetically modified plants is not constant and varies, and that may be due to a difference in type of explants, culture condition, PGR, genotypes, agrobacterium strain and plasmid type (Aisley et al. 2001; Wang et al. 2015). For peach, internodes (56.8\%), cotyledons (52.7\%), and embryonic axes (46.7\%) had the highest transformation rates where hypocotyl was less competent for transformation (Padilla et al. 2006). Also, previous study indicated the efficiency of TDZ comparing to other PGR to enhance agrobacterium-mediated transformation in Petunia hybrid, it shortened the duration of intermodal bud regeneration, in addition to reducing the somaclonal variations in most of the regenerated buds (Thirukkumaran et al. 2009).

\section{RT-PCR and Northern blot analysis}

Seven randomly selected putative transgenic peach plants were used for RT-PCR analysis to confirm $c r y 1 A b$ gene expression at transcript level. All seven transgenic plants showed the expected $1845 \mathrm{bp}$ amplified fragment in RT-PCR with $c r y 1 A b$ gene specific primers compared to non-transgenic peach plant (Fig. 6 a). Also, the results were showed that 190bp intron is removed by RNA splicing and gave $1845 \mathrm{bp}$ amplified fragment in RT-PCR. Also, accumulation of mRNA for the introduced $c r y 1 A b$ was determined in putative transgenic of peach plants using Northern blot analysis. The presence of a single $1845 \mathrm{bp}$ band obtained after splicing of a $190 \mathrm{bp}$ intron from the cry $1 \mathrm{Ab}$ gene showed higher level of gene expression at the transcriptional level compared to non transgenic peach plants (Fig. 6 b). 


\section{Cry1 Ab protein detection in transgenic peach plants}

The expression of Cry1Ab protein was assayed in the peach (Prunus persica L.) plants of PCR-positive transgenic plants via immune-strip test and insect bioassays.

\section{Immune-Strips assay}

Immune-Strips showed the band related to Cry $1 \mathrm{Ab}$ protein in the peach transgenic plants. The control band appeared in transgenic and nontransgenic plants, but Cry1 Ab protein bands just appeared in transgenic peach plant, but not appeared in the of non-transgenic peach plants (Fig. 7). The results indicated that high gene expression of Cry $1 \mathrm{Ab}$ protein in transgenic peach plants.

\section{Insect bioassay}

Insect bioassay of transformed peach (Prunus persica L.) plants with the Synanthedon exitiosa (peachtree borer) larvae's was performed and the mortality was recorded every 24 hours for four days. Table $\mathbf{3}$ shows the mortality percentage of Cry $1 \mathrm{Ab}$ toxin expressed in transgenic plants against Synanthedon exitiosa. The results indicated that the LC50 value from Cry1Ab toxin protein from transformed peach plants were 300 ppm against the Synanthedon exitiosa larvae's. The mortality percentage of Cry $1 \mathrm{Ab}$ toxin expressed in transgenic peach plants against Synanthedon exitiosa was $100 \%$ with 1000 ppm compared to the other treatments; as they reached 30, 50, 60 and $80 \%$ with 200, 400, 600 and 800 ppm from Cry1Ab toxin protein, respectively (Fig. 8). This data showed the high expression of $c r y 1 A b$ gene in the transformed peach plant.

In constructing plant expression vector pBI121-cry $1 \mathrm{Ab}$, the coding sequence of synthetic cry $1 \mathrm{Ab}$ was fused to CaMV35S promoter and the polyadenylation signal of the octopine synthase gene as described by Soliman et al. (2017). The combination of 35S promoter and the castor bean catalase1 intron has previously been demonstrated to confer high-level expression of foreign genes in transgenic plants (Tanaka et al., 1990). The stable integration of the cry1Ab gene, presence or absence of specific transcript and accumulation of mRNA was assured in plants using the RT-PCR and Southern blot analysis (Salehian et al. 2021). The copy number determination of transgenes in transgenic plants is important due to the effect of the copy number on the gene expression level and genetic stability. In our study highest gene expression of Cry1Ab protein in transgenic peach plants level was detected, however, this high rate is not necessarily expected in other experiments, as Ramirez-Romero et al. (2008) indicated that the Variability and significant differences of Cry $1 \mathrm{Ab}$ levels seems to occur related with the type of plant tissue, development stage and physiological conditions of transgenic plants. Our results in this study indicated the importance of Northern plot and Immune-Strips as of molecular analyzes to confirm the stability of crystal protein gene into transgenic peach genome. This result is in agreement with (Chen and Wu 2012). In our experiment a positive correlation between pest resistance and the mortality percentage of Cry1Ab toxin was detected. Kumar et al. (2010) showed that bioassay method and mortality were effective in identifying lines with intermediate to significant resistance against pest attack used. The interest in producing GMO from peaches cloning with Cry $1 \mathrm{Ab}$ gene is an important scientific 
development, where Rahnama et al. (2017) pointed out that the consumption of GMP food carrying Cry1 Ab had no effect on the growth rate, and general health status of the rats.

\section{Conclusion}

Peach (Prunus Persica L.) is an important deciduous fruit tree that is widely cultivated in the world. Peach is susceptible to many pests such as insects, virus, mites and borers which limit peach production. Modern methods of tissue culture and regeneration from in vitro leaves via indirect somatic embryogenesis using the method of genetic transfer are useful technique to impart the desired characteristics of peach plants. In this study, genetically peach modified with cry $1 \mathrm{Ab}$ gene that has inserted into peach genome by Agrobacterium, showed results are resistance to Synanthedon exitiosa larvae's. Various molecular analyzes confirmed that CrylAb toxin protein is stable integrated into peach genome. This paper is the first to have successfully used the Bt-cry $1 \mathrm{Ab}$ gene to produce genetically modified peach plants targeted to improve agricultural efficiency and product quality by acquisition of insect borer's resistance particularly the peach tree borer. These transgenic peach plants could be produced commercially in the future and cultivated to increase the productivity of peach fruits.

\section{Abbreviations}

BA: 6-Benzyladenine; bp: Base pairs; Cry: Crystal protein; IAA: Indole-3-acetic acid; IBA: Indole-3-butyric acid; 2iP: N-6-( $\Delta 2$-isopentenyl) adenine, Kn: kinetin, TDZ: Thiadiazuron (N-phenyl-N-1,2,3,-thiadiasol-5ylurea); 2,4-D: 2,4-Dichlorophenoxyacetic acid; WPM: Woody plant medium; MS: Murashige and Skoog's medium; nptl: Neomycin phosphotransferase; PCR: Polymerase chain reaction; RT-PCR: Reverse transcriptase polymerase chain reaction.

\section{Declarations}

\section{Acknowledgements}

The authors are thankful to the Tissue culture and Biotechnology Labs., Marout Research Station, Desert Research Center, Egypt.

Author contributions Naif Kadasa planned the whole work, performed the tissue culture experiments, helped in write up and designed the figures and tables. Ehab Metwali analyzed data, helped in write up, participated in the discussion results, contribution in the statistical analysis, reviewed several draft of the manuscript. Hemaid Soliman conceived the research, performed the experiment, conducted provided lab facilities, performed molecular analysis and submitted the MS. Wafa Alshehri helped in experimental accomplishment, reviewed and editing manuscript. All authors contributed to the final manuscript. All authors read and approved the manuscript.

\section{Compliance with ethical standards}


Conflict of interest The authors declare that they have no conflict of interest. The authors have no have no known competing financial interests or personal relationships that could have appeared to influence the work reported in this paper.

\section{References}

Abbasi H, Naderi R, Kafi M, Azadi P, Shakh-Asadi M, Okazaki K (2020) Effect of 'Chloroxynil'on Agrobacterium-mediated transformation efficiency of Lilium cv 'Manissa'.

Sci Hortic 271: doi.org/10.1016/j.scienta.2020.109404

Agdia (2003) Bt-cryIA(b)/IA(c) Immuno Strip Tests. Strip tests for the detection Bt- crylA(b)/IA(c) protein. Agdia Incorporated. Elkhart, Indiana, USA. p1-3.

Aisley PJ, Collins GG, Sedgley M (2001) Factors affecting Agrobacterium - mediated gene transfer and the selection of transgenic calli in paper shell almond (Prunus dulcis Mill.). J Hort Sci Biotechnol 76: $522-528$

Atia MA, Abdeldaym EA, Abdelsattar M, Ibrahim DS, Saleh I, Abd Elwahab M, Osman GH, Arif IA, Abdelaziz ME (2020) Piriformospora indica promotes cucumber tolerance against Root-knot nematode by modulating photosynthesis and innate responsive genes. Saudi J Biol Sci 27:279-287.

Balaraman K (2005) Occurrence and diversity of mosquitocidal strains of Bacillus thuringiensis. J Vector Borne Dis 42 :p.81.

Baranek J, Banaszak M, Lorent D, Kaznowski A, Konecka E (2020) Insecticidal activity of Bacillus thuringiensis Cry1, Cry2 and Vip3 toxin combinations in Spodoptera exigua control: highlights on synergism and data scoring. Entomologia Generalis.

Betz FS, Hammond BG, Fuchs RL (2000) Safety and advantages of Bacillus thuringiensis-protected plants to control insect pests. Regul Toxicol Pharmacol 32:156-173.

Bodh S, Singh D, Dogra RK, Chauhan N (2019) Comparative Response of Some Peach [Prunus persica (L.) Batsch.] Accessions for Tree, Foliage and Floral Traits. Int J Econ Plants 6:116-121.

Butko P (2003) Cytolytic toxin of Cyt1A and its mechanism of membrane damage: data and hypotheses. Appl Environ Microbiol 69:2415-2422.

CABI Crop Protection Compendium. (2014). Prunus persica (peach) datasheet. Available at: http://www.cabi.org/cpc/datasheet/44340.

Chen C, Wu JA (2012) Fast and Sensitive Quantitative Lateral Flow Immunoassay for Cry1Ab Based on a Novel Signal Amplification Conjugate. Sensors 12:11684-11696 
Cheng XY, Sardana R, Kaplan H, Altosaar I (1998) Agrobacterium-transformed rice plants expressing synthetic $c r y 1 A b$ and $c r y 1 A c$ genes are highly toxic to striped stem borer and yellow stem borer. Proc Natl Acad Sci 95:2767-2772.

Colby SM, Meredith CP (1990) Kanamycin sensitivity of cultured tissues of Vitis. Plant Cell Rep 9: 237240.

Cosson V, Eschstruth A, Ratet P (2015) Medicago truncatula transformation using leaf explants. In Agrobacterium Protocols (pp. 43-56). Springer, New York, NY.

Cottrell TE, Shapiro-llan DI (2006) Susceptibility of the peachtree borer, Synanthedon exitiosa, to Steinernema carpocapsae and Steinernema riobrave in laboratory and field trials. J Invertebr Pathol 92:85-88.

Declerck V, Korban SS (1996) Influence of growth regulators and carbon sources on callus induction, growth and morphogenesis from leaf tissues of peach (Prunus persica L. Batsch). J Hortic Sci 71: 49-55.

Dulmage HT (1971) Production of delta-endotoxin by 18 isolates of Bacillus thuringiensis, serotype 3 , in 3 fermentation media. J Invertebr Pathol 18:353-58.

Dulmage HT, Boening OP, Rehnborg CS, Hansen GD (1971) A proposed standardized bioassay for formulations of Bacillus thuringiensis based on the international unit. J Invertebr Pathol 18: 240-245

Dutton A, Romeis J, Bigler F (2005) Effects of Btmaize expressing Cry1Ab and Bt spray on Spodoptera littoralis. The Netherlands Entomological Society, 114: 161-169

Dutton A, Romeis J, Bigler F (2005) Effects of Bt maize expressing Cry1 Ab and Bt spray on Spodoptera littoralis. Entomol Exp App 114: 161-169.

El-Gaied L, Mahmoud A, Salem R, Elmenofy W, Saleh I, Abulreesh HH, Arif IA, Osman G (2020) Characterization, cloning, expression and bioassay of vip3 gene isolated from an Egyptian Bacillus thuringiensis against whiteflies. Saudi J Biol Sci 27:1363-1367.

Ferry N, Edwards MG, Gatehouse JA, Gatehouse AM (2004) Plant-insect interactions: molecular approaches to insect resistance. Curr Opin Biotechnol 15:155-161.

Food and Agriculture Organization (2020) http://www.fao.org/faostat/en/\#data/QC/visualize

Gentile A, Monticelli S, Damiano C (2003) Adventitious shoot regeneration for Agrobacterium-mediated transformation in Prunus. Acta Hortic 616:331-333

Gentile A, Monticelli S, Damiano D (2002) Adventitious shoot regeneration in peach (Prunus persica L. Bastsch). Plant Cell Rep 20: 1011-1016 
Gomez I, Sanchez J, Munoz-garay C, Matus V, GILL SS, Soberon M, Bravo A (2014) Bacillus thuringiensis Cry $1 \mathrm{~A}$ toxins are versatile proteins with multiple modes of action: two distinct pre-pores are involved in toxicity. Biochem J 459:383-396

Hofte H, Whiteley HR (1989) Insecticidal crystal proteins of Bacillus thuringiensis. Microbiol Rev 53:242255

Isa A, Khadr GD (1973) Rearing of Ostirinia nubilalis (Hub.) on artificial diets. Agric Res Rev Cairo 51:1519.

Jenkins JL, Dean DH (2000) Exploring the Mechanism of Action of Insecticidal Proteins by Genetic Engineering Methods. In: Setlow J.K. (eds) Genetic Engineering. Genetic Engineering (Principles and Methods), vol 22. Springer, Boston, MA. https://doi.org/10.1007/978-1-4615-4199-8_4

John ME (1997) Cotton crop improvement through genetic engineering. Crit Rev Biotechnol 17:185-208.

Johnson D, Cottrell T, Horton D (2005) Lesser peachtree borer. Southeastern peach growers' handbook. GES Handbook, (1), pp.270-272.

Johnson D, Cottrell T, Horton D (2005) Peachtree borer. In: Horton, D., Johnson, D. (Eds.), Southeastern Peach Grower's Handbook. Univ. GA Coop. Ext. Serv., G.E.S. Handbook No. 1, pp. 266-269.

King DR, Morris HF (1956) Biologies of the peach tree borer and lesser peach tree borer in east Texas. J Eco Entomol 49: 397-398.

Kranthi KR, Stone GD (2020) Long-term impacts of Bt cotton in India. Nature Plants 6:188-196.

Kumar H, Kumar V (2004) Tomato expressing Cry1 A(b) insecticidal protein from Bacillus thuringiensis protected against tomato fruit borer, Helicoverpa armigera (Hübner) (Lepidoptera: Noctuidae) damage in the laboratory, greenhouse and field. Crop Prot 23:135-139

Kumar M, Chimote V, Singh R, Mishra GP, Naik PS, Pandey SK, Chakrabarti SK (2010) Development of Bt transgenic potatoes for effective control of potato tuber moth by using cry $1 \mathrm{Ab}$ gene regulated by GBSS promoter. Crop Prot 29:121-127.

Li ZT, Dhekney S, Dutt M, Van Aman M, Tattersall J, Kelley KT, Gray DJ (2006) Optimizing Agrobacteriummediated transformation of grapevine. In Vitro Cell Dev Biol Plant 42:220-227

Lloyd G, McCown B (1980) Commercially-feasible micropropagation of mountain laurel, Kalmia latifolia, by use of shoot-tip culture. Proc Int Plant Prop Soc 30: 421-427.

Metwali EM, Soliman HI, Fuller MP, Almaghrabi OA (2015) Improving fruit quality in tomato (Lycopersicum esculentum Mill) under heat stress by silencing the vis 1 gene using small interfering RNA technology. Plant Cell Tiss Organ Cult 121:153-166. 
Metwali EM, Soliman HI, Fuller MP, Al-Zahrani HS, Howladar SM (2015) Molecular cloning and expression of a vacuolar $\mathrm{Na}+/ \mathrm{H}+$ antiporter gene (AgNHX1) in fig (Ficus carica L.) under salt stress. Plant Cell Tiss Organ Cult 123:377-387.

Miguel CM, Druart P, Oliveira MM (1996) Shoot regeneration from adventitious buds induced on juvenile and adult almond (Prunus dulcis Mill.) explants. In Vitro Cell Dev Biol Plant 32:148-153.

Murashige T, Skoog F (1962) A revised medium for rapid growth and bioassays with tobacco tissue cultures. Physiol Plant 15: 473-479

Ogawa JM, Zehr El, Bird GW, Ritchie DF, Uriu K, Uyemoto JK (1995) Compendium of stone fruit diseases. APS Press, St. Paul, MN, USA.

Orbović V (2019) New developments in Agrobacterium-mediated transformation of tree fruit crops. Front Plant Sci 10:1253.

Oropeza-Aburto A, Cervantes-Perez S, Albert VA, Herrera-Estrella L (2020) Agrobacterium tumefaciens mediated transformation of the aquatic carnivorous plant Utricularia gibba. Plant Method 16:1-11.

Padilla IM, Golis A, Gentile A, Damiano C, Scorza R (2006) Evaluation of transformation in peach Prunus persica explants using green fluorescent protein (GFP) and beta-glucuronidase (GUS) reporter genes. Plant Cell Tiss Organ Cult 84:309-314.

Pardo Lopez L, Soberon M, Bravo A (2013) Bacillus thuringiensis insecticidal three-domain Cry toxins: mode of action, insect resistance and consequences for crop protection. FEMS Microbiol Rev 37:3-22

Pasternak T, Prinsen E, Ayaydin F, Miskolczi P, Potters G, Asard H, Van Onckelen H, Dudits D, Fehe'r A (2002) The role of auxin, $\mathrm{pH}$ and stress in the activation of embryogenic cell division in leaf protoplastderived cells of alfalfa (Medicago sativa L.). Plant Physiol 129:1807-1819

Pérez-Jiménez M, López-Soto MB, Cos-Terrer J (2013) In vitro callus induction from adult tissues of peach (Prunus persica L. Batsch). In Vitro Cell Dev Biol Plant 49:79-84

Petri C, Scorza R, Srinivasan C (2012) Highly efficient transformation protocol for plum (Prunus domestica L.). In Transgenic Plants (pp. 191-199). Humana Press

Petri C, Wang H, Alburquerque N, Faize M, Burgos L (2008) Agrobacterium-mediated transformation of apricot (Prunus armeniaca L.) leaf explants. Plant Cell Rep 27: 1317-1324.

Poitout S, Bues R (1974) Elevage de plusieursesepeces de Lepidopteres Noctuidae sur milieu artificiel simplifié. [Breeding of several species of Lepidoptera Noctuidae on simplifies artifical diet]. Ann Zool Ecol Anim 2:79-91 
Rahnama H, Nikmard M, Abolhasani M, Osfoori R, Sanjarian F, Habashi AA (2017) Immune analysis of cry1 Ab-genetically modified potato by in-silico analysis and animal mode I. Food Sci Biotechnol 26:14371445.

Ramirez-Romero, R., Desneux, N., Chaufaux, J. and Kaiser, L., 2008. Bt-maize effects on biological parameters of the non-target aphid Sitobion avenae (Homoptera: Aphididae) and Cry $1 \mathrm{Ab}$ toxin detection. Pestic Biochem Physiol 91:110-115.

Ranjekar PK, Patankar A, Gupta V, Bhatnagar R, Bentur J, Kumar PA (2003) Genetic engineering of crop plants for insect resistance. Curr Sci 84:321-329.

Reilly CC, Gentry CR, McVay JR (1987) Biochemical evidence for resistance of rootstocks to the peachtree borer and species separation of peachtree borer and lesser peachtree borer (Lepidoptera: Sesiidae) on peach trees. J Eco Entomol 80: 338-343.

Reis RS, Vale EM, Sousa KR, Santa-Catarina C, Silveira V (2021) Pretreatment free of 2, 4dichlorophenoxyacetic acid improves the differentiation of sugarcane somatic embryos by affecting the hormonal balance and the accumulation of reserves. Plant Cell Tiss Organ Cult 145:101-115

Ricci A, Capriotti L, Mezzetti B, Navacchi O, Sabbadini S (2020) Adventitious Shoot Regeneration from In Vitro Leaf Explants of the Peach Rootstock Hansen 536. Plants 9: 755

Ricci A, Sabbadini S, Prieto H, Padilla IM, Dardick C, Li Z, Scorza R, Limera C, Mezzetti B, Perez-Jimenez M, Burgos L (2020) Genetic Transformation in Peach (Prunus persica L.): Challenges and Ways Forward. Plants 9:971

Sabbadini S, Capriotti L, Molesini B, Pandolfini T, Navacchi O, Limera C, Ricci A, Mezzetti B (2019) Comparison of regeneration capacity and Agrobacterium-mediated cell transformation efficiency of different cultivars and rootstocks of Vitis spp. via organogenesis. Sci Rep 9:1-10.

Sabbadini S, Ricci A, Limera C, Baldoni D, Capriotti L, Mezzetti B (2019) Factors Affecting the Regeneration, via Organogenesis, and the Selection of Transgenic Calli in the Peach Rootstock Hansen 536 (Prunus persica $\times$ Prunus amygdalus) to Express an RNAi Construct against PPV Virus. Plants 8:178.

Salehian H, Rahnama H, Dezhsetan S and Babaei S (2021) Constitutive expression of a synthetic cry1Ab gene confers resistance to potato tuber moth (Phthorimaea operculella Zeller) larva. Crop Breed App Biotechnol 21(1):1-9.

San B, Li Z, Hu Q, Reighard G L, Luo H (2014) Adventitious shoot regeneration from in vitro cultured leaf explants of peach rootstock Guardianfi is significantly enhanced by silver thiosulfate. Plant Cell Tiss Organ Cult 120:757-765.

Schnepf E, Crickmore NV, Van Rie J, Lereclus D, Baum J, Feitelson J, Zeigler DR, Dean D (1998) Bacillus thuringiensis and its pesticidal crystal proteins. Microbiol Mol Biol Rev 62:775-806. 
Shapiro-llan DI, Cottrell TE, Mizell RF, Horton DL, Davis J (2009) A novel approach to biological control with entomopathogenic nematodes: Prophylactic control of the peach tree borer, Synanthedon exitiosa. Biol Control 48: 259-263.

Shapiro-llan DI, Cottrell TE, Mizell RF, Horton DL, Zaid A (2015) Field suppression of the peachtree borer, Synanthedon exitiosa, using Steinernema carpocapsae: Effects of irrigation, a sprayable gel and application method. Biol Control 82:7-12.

Shaw CH, Leemans J, Shaw CH, Van Montagu M, Schell J (1983) A general method for the transfer of cloned genes to plant cells. Gene 23:315-330.

Sidorova T, Mikhailov R, Pushin A, Miroshnichenko D, Dolgov S (2019) Agrobacterium-Mediated Transformation of Russian Commercial Plum cv. "Startovaya" (Prunus domestica L.) With Virus-Derived Hairpin RNA Construct Confers Durable Resistance to PPV Infection in Mature Plants. Plant Sci 10:286.

Sidorova T, Mikhailov R, Pushin A, Miroshnichenko D, Dolgov S (2017) A non-antibiotic selection strategy uses the phosphomannose-isomerase ( $P M I)$ gene and green fluorescent protein (GFP) gene for Agrobacterium-mediated transformation of Prunus domestica L. leaf explants. Plant Cell Tiss Organ Cult 128:197-209

Soliman HI (2013) In vitro regeneration and genetic transformation of peach (Prunus persica L.) plants. Life Sci J 10: 487-496.

Soliman HI, Abo-El-Hasan F, El-seedy A S and Mabrouk Y M (2017). Agrobacterium-mediated transformation and regeneration of transgenic tomato (Lycopersicon esculentum Mill.) plants using a synthetic $c r y 1 \mathrm{Ab}$ gene for enhanced resistance against Tuta absoluta (Meyrick). J Microbiol Biotechnol Food Sci 7 (1): 67-74.

Song GQ, Prieto H, Orbovic V (2019) Agrobacterium-mediated transformation of tree fruit crops: methods, progress, and challenges. Front Plant Sci 10:226.

Song GQ, Sink KC (2005) Optimizing shoot regeneration and transient expression factors for Agrobacterium tumefaciens transformation of sour cherry (Prunus cerasus L.) cultivar Montmorency. Sci Hortic 106:6

Souza ADG, Chalfun NNJ, Faquin V, Souza AAD (2011) Production of peach grafts under hydroponic conditions. Ciência e Agrotecnologia 35: 322-326.

Steel RG, Torrie JH, Dickey DA (1997) Principles and procedures of statistics a biometrical approach 3rd ed. McGraw Hill Book Co. Inc., New York, USA.

Steel RGD, Torrie JH (1960) Principles and procedures of statistics. Principles and procedures of statistics. 
Tabashnik BE, Cushing NL, Finson N, Johnson MW (1990) Field development of resistance to Bacillus thuringiensis in diamondback moth (Lepidoptera: Plutellidae). J Econ J Economic Entomol 83:16711676.

Tanaka A, Mita S, Ohta S, Kyozuka J, Shimamoto K. and Nakamura K. (1990) Enhancement of foreign gene expression by a dicot intron in Rice but not in tobacco is correlated with an increased level of mRNA and an efficient splicing of the intron. Nucl Acid Res 18, 6767-6770.

Thirukkumaran G, VO Ntui, RS Khan, M Mii (2009) Thidiazuron: an efficient plant growth regulator for enhancing Agrobacterium-mediated transformation in Petunia hybrida. Plant Cell Tiss Organ Cult 99:109-115

Wang Y, Georgi LL, Reighard GL, Scorza R, Abbott AG (2002) Genetic mapping of the evergrowing gene in peach [Prunus persica (L.) Batsch]. J Hered 93:352-358.

Xu C, Cheng J, Lin H, Lin C, Gao J, Shen Z (2018) Characterization of transgenic rice expressing fusion protein Cry1Ab/Vip3A for insect resistance. Sci Rep 8:1-8

Xu S, Lai E, Zhao L, Cai Y, Ogutu C, Cherono S, Han Y, Zheng B (2020) Development of a fast and efficient root transgenic system for functional genomics and genetic engineering in peach. Sci Rep 10:1-9.

Yan Y, Yu TF, Ma J, Chen J, Zhou YB, Chen M, Ma YZ, Wei WL, Xu ZS (2020) The soybean bZIP transcription factor gene GmbZIP2 confers drought and salt resistances in transgenic plants. Int J Mol Sci 21:670.

Ye GY, Shu QY, Yao HW, Cui HR, Cheng XY, Hu C, Xia YW, Gao MW, Altosaar I (2001) Field evaluation of resistance of transgenic rice containing a synthetic cry $1 \mathrm{Ab}$ gene from Bacillus thuringiensis Berliner to stem borers. J Econ Entomol 94:271-276

Zhang BH, Liu F, Liu ZH, Wang HM, Yao CB (2001) Effects of kanamycin on tissue culture and somatic embryogenesis in cotton. Plant Grow Regul 33:137-149.

Zhou H, Li M, Zhao X, Fan X, Guo A (2010) Plant regeneration from in vitro leaves of the peach rootstock 'Nemaguard'(Prunus persicax P. davidiana). Plant Cell Tiss Organ Cult 101:79-87

Zuo JR, Niu QW, Frugis G, Chua NH (2002) The wuschel gene promotes vegetative-to-embryonic transition in Arabidopsis. Plant J 30: 349-359.

\section{Tables}

Table 1 The best of different concentrations of plant growth regulators and various culture media on callus induction of peach (Prunus Persica L.) after four weeks. 


\section{Culture medium and concentration of plant growth regulators}

MS (Murashige and Skoog 1962) medium

\begin{tabular}{|c|c|c|c|c|}
\hline 2,4-D & Kinetin & BAP & & weight (g) \\
\hline 2.0 & 0.0 & 0.5 & $33.8 \pm 0.27 i$ & $2.25 \pm 0.18 \mathrm{i}$ \\
\hline 2.5 & 0.0 & 0.5 & $49.5 \pm 0.38 \mathrm{~h}$ & $2.48 \pm 0.23 h$ \\
\hline 3.0 & 0.0 & 1.0 & $84.9 \pm 0.57 c$ & $3.55 \pm 0.44 c$ \\
\hline 3.5 & 0.0 & 1.0 & $\mathrm{e} \pm 0.2476 .5$ & $\pm 0.67 \mathrm{~d} 3.47$ \\
\hline 4.0 & 0.0 & 1.5 & $55.2 \pm 0.72 \mathrm{~g}$ & $\pm 0.38 \mathrm{e} 3.25$ \\
\hline 2.0 & 1.0 & 0.0 & $\pm 0.19 \mathrm{j} 27.0$ & $1.85 \pm 0.25 j$ \\
\hline 2.5 & 1.0 & 0.0 & $\pm 0.34 \mathrm{i} 38 . .3$ & $2.05 \pm 0.82 i$ \\
\hline 3.0 & 1.5 & 0.0 & $58.4 \pm 0.65 \mathrm{~g}$ & $2.65 \pm 0.77 \mathrm{~g}$ \\
\hline 3.5 & 1.5 & 0.0 & $52.7 \pm 0.39 \mathrm{~g}$ & $\pm 0.62 \mathrm{~h} 2.55$ \\
\hline 4.0 & 2.0 & 0.0 & $41.8 \pm 0.52 \mathrm{~h}$ & $2.29 \pm 0.38 \mathrm{i}$ \\
\hline \multicolumn{5}{|c|}{ WPM (Lloyd and McCown 1980) medium } \\
\hline 2,4-D & Kinetin & BAP & & \\
\hline 2.0 & 0.0 & .50 & $85.2 \pm 0.88 \mathrm{c}$ & $2.68 \pm 0.79 \mathrm{~g}$ \\
\hline 2.5 & 0.0 & 0.5 & $89.5 \pm 0.93 a$ & $3.78 \pm 0.65 a$ \\
\hline 3.0 & 0.0 & 1.0 & $87.8 \pm 0.74 b$ & $3.68 \pm 0.52 b$ \\
\hline 3.5 & 0.0 & 1.0 & $81.4 \pm 0.68 d$ & $\pm 0.48 \mathrm{c} 3.52$ \\
\hline 4.0 & 0.0 & 1.5 & $66.5 \pm 0.54 f$ & $\pm 0.62 \mathrm{~d} 3.40$ \\
\hline 2.0 & 1.0 & 0.0 & $39.8 \pm 0.26 i$ & $2.05 \pm 0.39 i$ \\
\hline 2.5 & 1.0 & 0.0 & $h \pm 0.3744 .5$ & $2.35 \pm 0.42 \mathrm{i}$ \\
\hline 3.0 & 1.5 & 0.0 & $f \pm 0.5165 .2$ & $2.85 \pm 0.60 f$ \\
\hline 3.5 & 1.5 & 0.0 & $f \pm 0.4262 .5$ & $\mathrm{~g} \pm 0.782 .67$ \\
\hline 4.0 & 2.0 & 0.0 & $\pm 0.38 \mathrm{~g} 55.3$ & $2.49 \pm 0.82 \mathrm{~h}$ \\
\hline
\end{tabular}

Means followed by the same letters in the column do not differ by the Duncan test $(p \leq 0.05)$. Value

represents the mean \pm standard error (S.E.) of ten replicates per treatment in three repeated experiments Table 2 The best plant growth regulators concentrations and various culture media on adventitious bud regeneration efficiency of peach (Prunus Persica L.) after six weeks.

\section{$\%$ of explants formed} callus

Callus fresh weight (g) $2.25 \pm 0.18 \mathrm{i}$ $2.48 \pm 0.23 \mathrm{~h}$ $3.55 \pm 0.44 \mathrm{c}$ $\pm 0.67 \mathrm{~d} 3.47$ $\pm 0.38 \mathrm{e} 3.25$ $1.85 \pm 0.25 j$ $2.05 \pm 0.82 \mathrm{i}$ $2.65 \pm 0.77 \mathrm{~g}$ $\pm 0.62 \mathrm{~h} 2.55$ $2.29 \pm 0.38 \mathrm{i}$
WPM (Lloyd and McCown 1980) medium 


\section{Culture medium and concentration of plant growth regulators \\ $\%$ of callus formed shoots \\ NO. of adventitious buds/callus \\ Mean shoot length $(\mathrm{cm})$}

MS (Murashige and Skoog medium1962)

\begin{tabular}{lllllll|} 
TDZ & IAA & BAP & Kinetin & & & \\
\hline 1.0 & 0.0 & 2.0 & 0.0 & $\pm 0.42 \mathrm{j} 38.5$ & $3.55 \pm 0.22 \mathrm{i}$ & $\pm 0.42 \mathrm{j} 1.29$ \\
\hline 2.0 & 0.0 & 1.0 & 1.0 & $\pm 0.55 \mathrm{i} 43.9$ & $\mathrm{~h} \pm 0.394 .05$ & $\pm 0.59 \mathrm{j} 1.37$ \\
\hline 2.0 & 0.5 & 2.0 & 0.0 & $\mathrm{~g} \pm 0.7165 .8$ & $\mathrm{e} \pm 0.575 .32$ & $\pm 0.66 \mathrm{i} 1.89$ \\
\hline 3.0 & 0.0 & 0.5 & 1.0 & $\pm 0.68 \mathrm{~h} 53.4$ & $\mathrm{~g} \pm 0.394 .35$ & $\pm 0.54 \mathrm{i} 1.78$ \\
\hline 3.0 & 0.5 & 0.0 & 0.0 & $\pm 0.83 \mathrm{~d} 79.5$ & $\mathrm{~d} \pm 0.655 .90$ & $\pm 0.65 \mathrm{~g} 2.95$ \\
\hline 3.0 & 0.5 & 0.0 & 1.0 & $\pm 0.92 \mathrm{~b} 88.5$ & $\mathrm{~b} \pm 0.837 .25$ & $\pm 0.81 \mathrm{~b} 3.70$ \\
\hline 4.0 & 0.5 & 0.5 & 1.0 & $\pm 0.79 \mathrm{c} 82.4$ & $\mathrm{C} \pm 0.696 .15$ & $\pm 0.79 \mathrm{~d} 3.48$ \\
\hline 4.0 & 0.5 & 0.0 & 0.0 & $\pm 0.77 \mathrm{f} 68.3$ & $\mathrm{~d} \pm 0.785 .70$ & $\pm 0.68 \mathrm{f} 3.05$ \\
\hline 5.0 & 0.0 & 0.0 & 1.0 & $66.4 \pm 0.59 \mathrm{~g}$ & $\mathrm{~h} \pm 0.364 .00$ & $\pm 0.77 \mathrm{~g} 2.84$ \\
\hline $\begin{array}{l}\text { WPM (Lloyd and McCown } \\
\text { medium }\end{array}$ & & & & & & \\
\hline TDZ & IAA & BAP & Kinetin & & & \\
\hline 1.0 & 0.0 & 2.0 & 0.0 & $\pm 0.61 \mathrm{i} 49.7$ & $\mathrm{~g} \pm 0.314 .28$ & $\pm 0.29 \mathrm{~h} 2.28$ \\
\hline 2.0 & 0.0 & 1.0 & 1.0 & $\pm 0.73 \mathrm{~h} 55.5$ & $\mathrm{f} \pm 0.594 .65$ & $\pm 0.46 \mathrm{~h} 2.42$ \\
\hline 2.0 & 0.5 & 2.0 & 0.0 & $\pm 0.84 \mathrm{e} 70.2$ & $\mathrm{~d} \pm 0.685 .78$ & $\pm 0.61 \mathrm{f} 2.98$ \\
\hline 3.0 & 0.0 & 0.5 & 1.0 & $\mathrm{~g} \pm 0.7366 .5$ & $\mathrm{f} \pm 0.444 .89$ & $2.85 \pm 0.59 \mathrm{~g}$ \\
\hline 3.0 & 0.5 & 0.0 & 0.0 & $\pm 0.39 \mathrm{c} 82.3$ & $\mathrm{C} \pm 0.786 .25$ & $\pm 0.72 \mathrm{~d} 3.40$ \\
\hline 3.0 & 0.5 & 0.0 & 1.0 & $\pm 0.55 \mathrm{a} 91.8$ & $8.75 \pm 0.89 \mathrm{a}$ & $3.87 \pm 0.94 \mathrm{a}$ \\
\hline 4.0 & 0.5 & 1.0 & 1.0 & $\pm 0.65 \mathrm{~b} 89.2$ & $\mathrm{~b} \pm 0.757 .39$ & $\pm 0.86 \mathrm{c} 3.65$ \\
\hline 4.0 & 0.5 & 0.0 & 0.0 & $78.5 \pm 0.47 \mathrm{~d}$ & $\mathrm{C} \pm 0.696 .00$ & $\pm 0.65 \mathrm{e} 3.25$ \\
\hline 5.0 & 0.0 & 0.0 & 1.0 & $71.9 \pm 0.81 \mathrm{e}$ & $\mathrm{f} \pm 0.624 .95$ & $3.00 \pm 0.59 \mathrm{f}$ \\
\hline
\end{tabular}

Means followed by the same letters in the column do not differ by the Duncan test $(p \leq 0.05)$. Value represents the mean \pm standard error (S.E.) of ten replicates per treatment in three repeated experiments

Table 3 Insect bioassay of peach (Prunus Persica L.) transformed plants against Synanthedon exitiosa (peach tree borer) larvae's of expressing the cry 1 ab gene after four days of Bioassay on Semi-Artificial diet. 
Lethal concentration larvae's)peach tree borer( Synanthedon exitiosa

50 (LC50) Mortality percentage/concentration (ppm) Peach plants

\begin{tabular}{lllllll} 
& 200 & 400 & 600 & 800 & 1000 & \\
\cline { 1 - 5 }- & $0 \%$ & $0 \%$ & $0 \%$ & $0 \%$ & $0 \%$ & Nontransformed plants \\
\hline $300 \mathrm{ppm}$ & 30 & 50 & 60 & 80 & 100 & Transformed plants
\end{tabular}

\section{Figures}

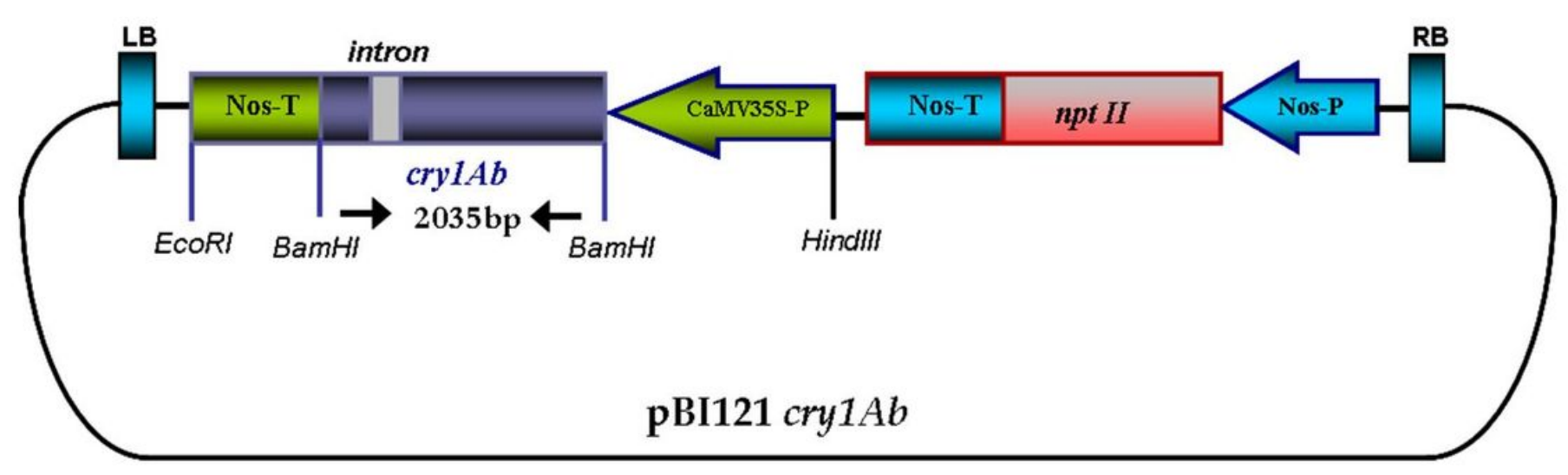

Figure 1

Restriction map of the binary vector pBI 121 cry $1 \mathrm{Ab}$ carrying the synthetic cry $1 \mathrm{Ab}$ gene containing the first intron of castor bean catalase-1 gene was driven by the CaMV35S promoter and nopaline synthase terminator with Kamamycin-resistance gene (npt II) was driven by the Nos promoter and Nos terminator. LB, left border; RB, right border; nptll, neomycin phosphotransferase;CaMV35S-P,cauliflower mosaic virus promoter Nos-P, nopaline synthase promoter; Nos-T, nopaline synthase terminator. 


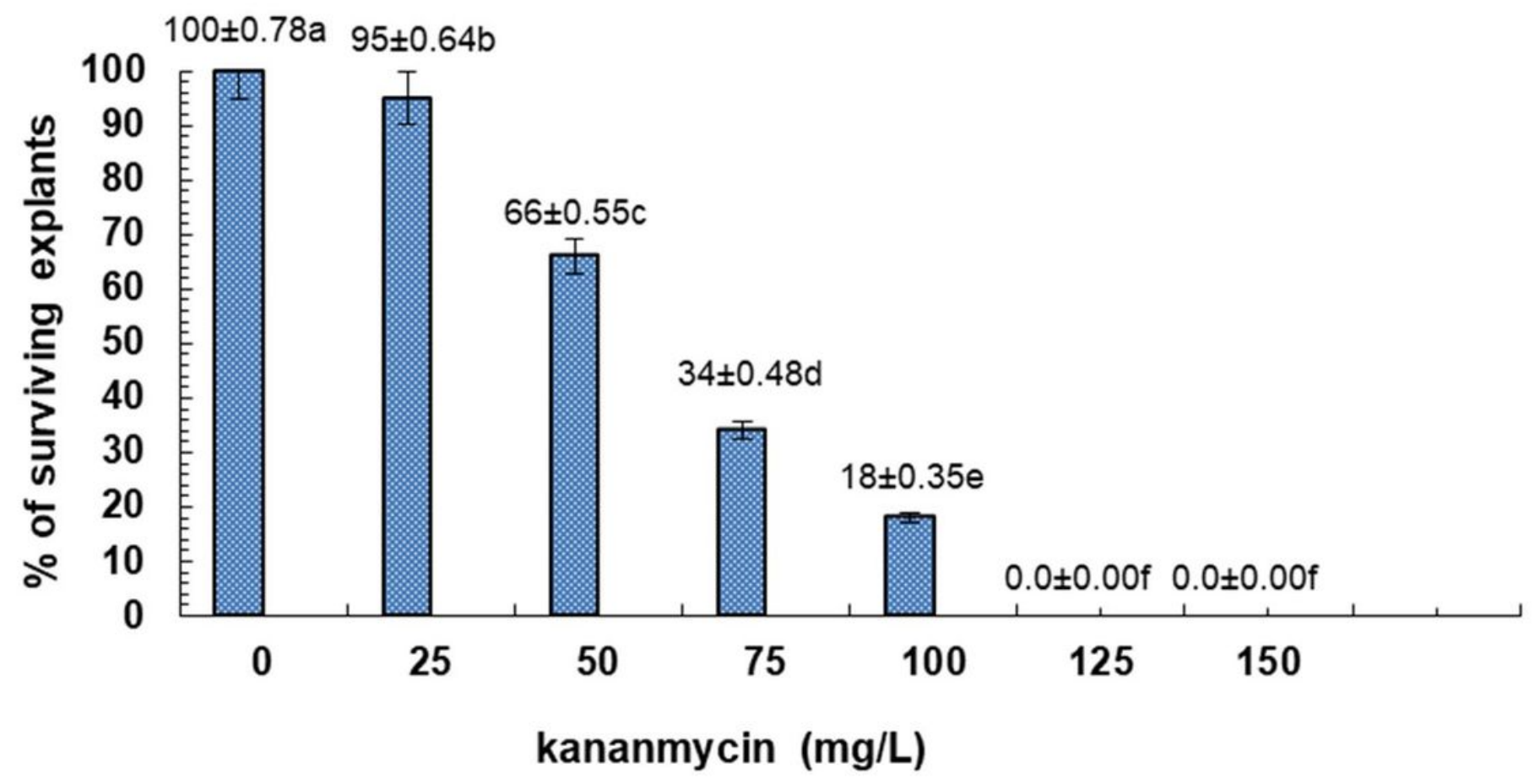

Figure 2

Effect of kanamycin concentrations on leaf segments of peach (Prunus persica L.) plants. 


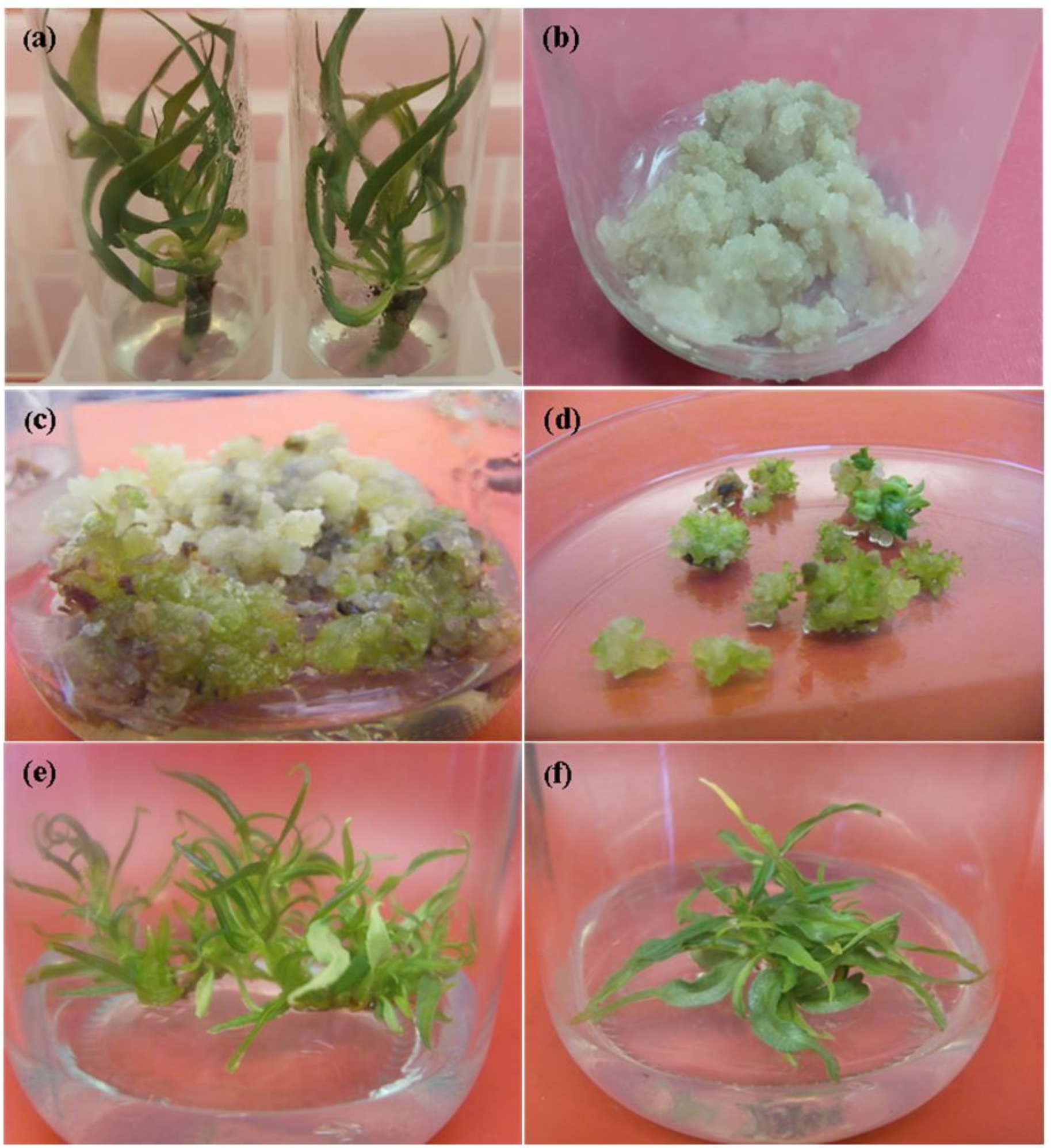

\section{Figure 3}

Adventitious shoot regeneration from in vitro leaves of peach. a Leaf explants from in vitro shoots that were previously propagated by stem node sections on MS medium $2.0 \mathrm{mg} \mathrm{L}-1 \mathrm{BA}$ and $0.2 \mathrm{mg} \mathrm{L}-1 \mathrm{BBA} ; \mathrm{b}$ Callus formation from leaf explants on WPM medium supplemented with $2.5 \mathrm{mg}$ L-12,4-D and $0.5 \mathrm{mg}$ L1BAP; c Nodular type callus conducive to adventitious bud formation and shoot differentiation; $d$ 
Adventitious shoots induction from callus on WPM medium supplemented with $3.0 \mathrm{mg}$ L-1,1.0 mg L1 kinetin and $0.5 \mathrm{mg} \mathrm{L-1}$ IAA after 35 days; e and f. Developed shoot after 45 and 60 days.

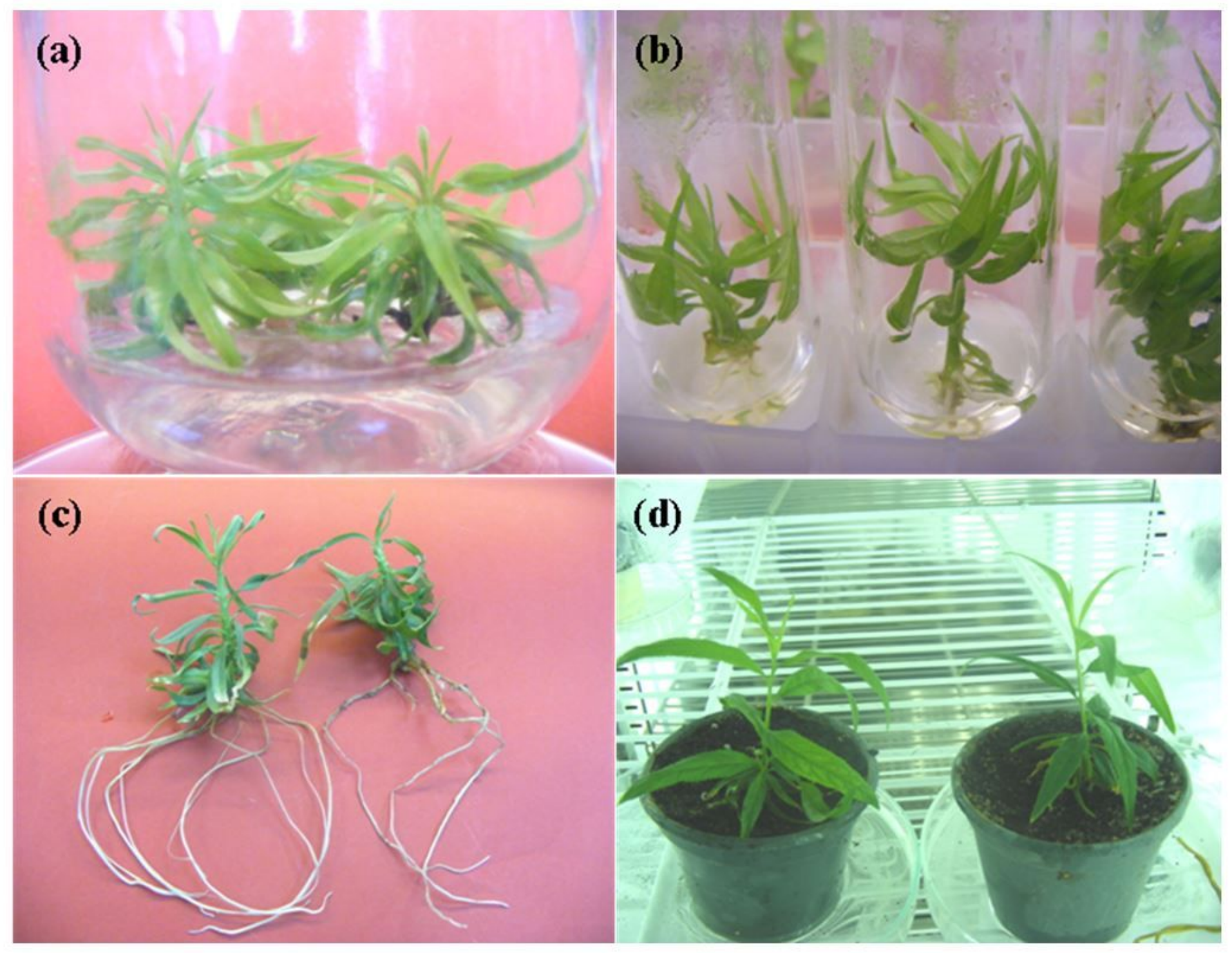

\section{Figure 4}

In vitro propagation stages of regenerated transformed peach plants. a elongated shoots were cultured on MS medium containing $0.52 \mathrm{iP}$ after one month; $b$ Root formation on liquid MS medium supplemented with $2.0 \mathrm{mg} \mathrm{L}-1$ IBA and $0.5 \mathrm{mg} \mathrm{L}-1$ NAA and $162 \mathrm{mg} \mathrm{L-1}$ phloroglucinol after 21 days; C after 45 days; $d$ Acclimatization of transformed peach plants. 


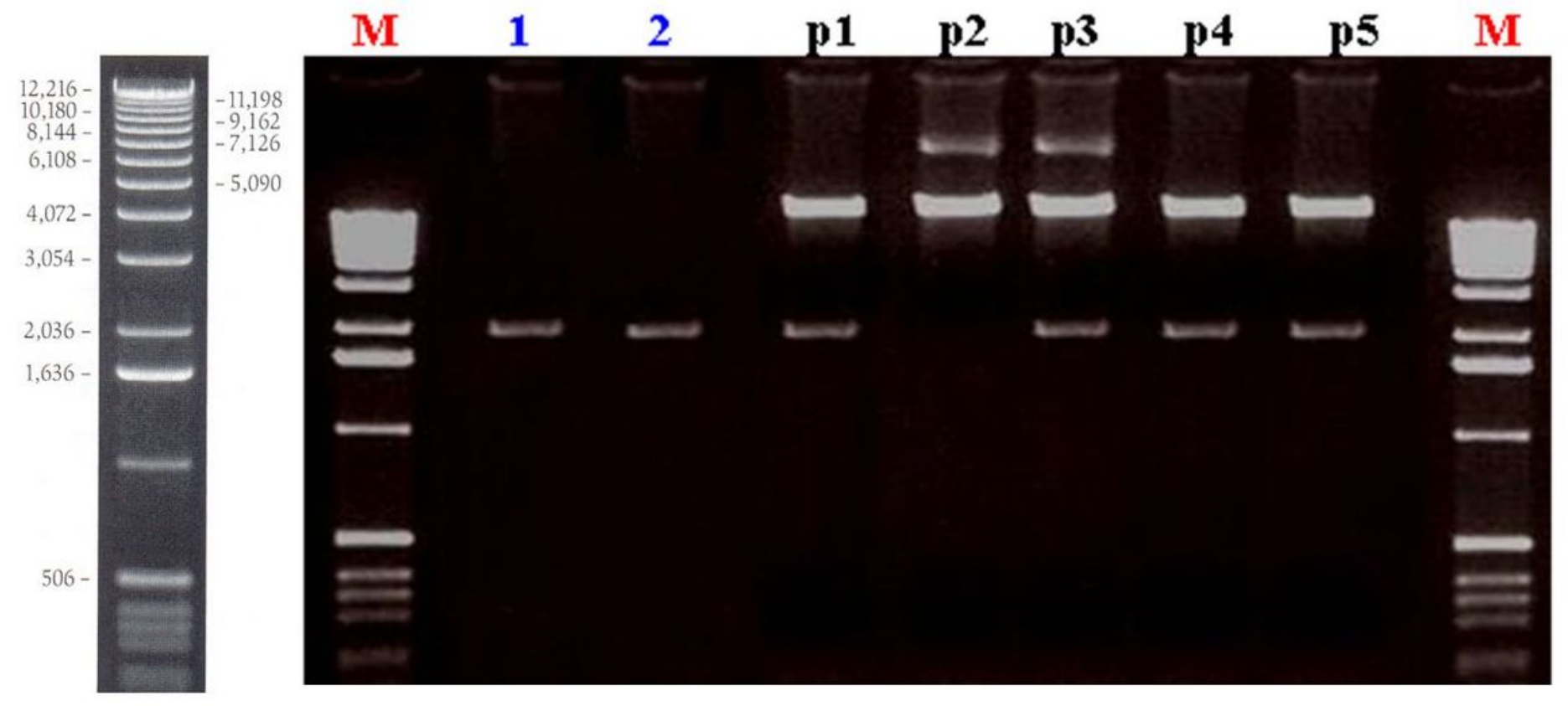

Figure 5

Molecular analysis of the cry $1 \mathrm{Ab}$ gene in peach (Prunus persica L.). PCR detection of cry $1 \mathrm{Ab}$ gene with intron in putative transgenic peach plants, amplifying about $2.035 \mathrm{~kb}$ with transgenic plants (Lanes 1-2). $\mathrm{pBI} 121 \mathrm{cry} 1 \mathrm{Ab}$ digested with BamHI to release the binary plasmid vector pBI121 (upper band) along with the insert cry1 Ab gene with intron (2.035kb lower band) (Lanes p1, p2, p4 and p5) compared with the binary plasmid vector pBI121 without cry1Ab gene (Lane p2). Lane M: Tracklt ${ }^{\mathrm{TM}} 1 \mathrm{~Kb}$ DNA Ladder. 
(a)
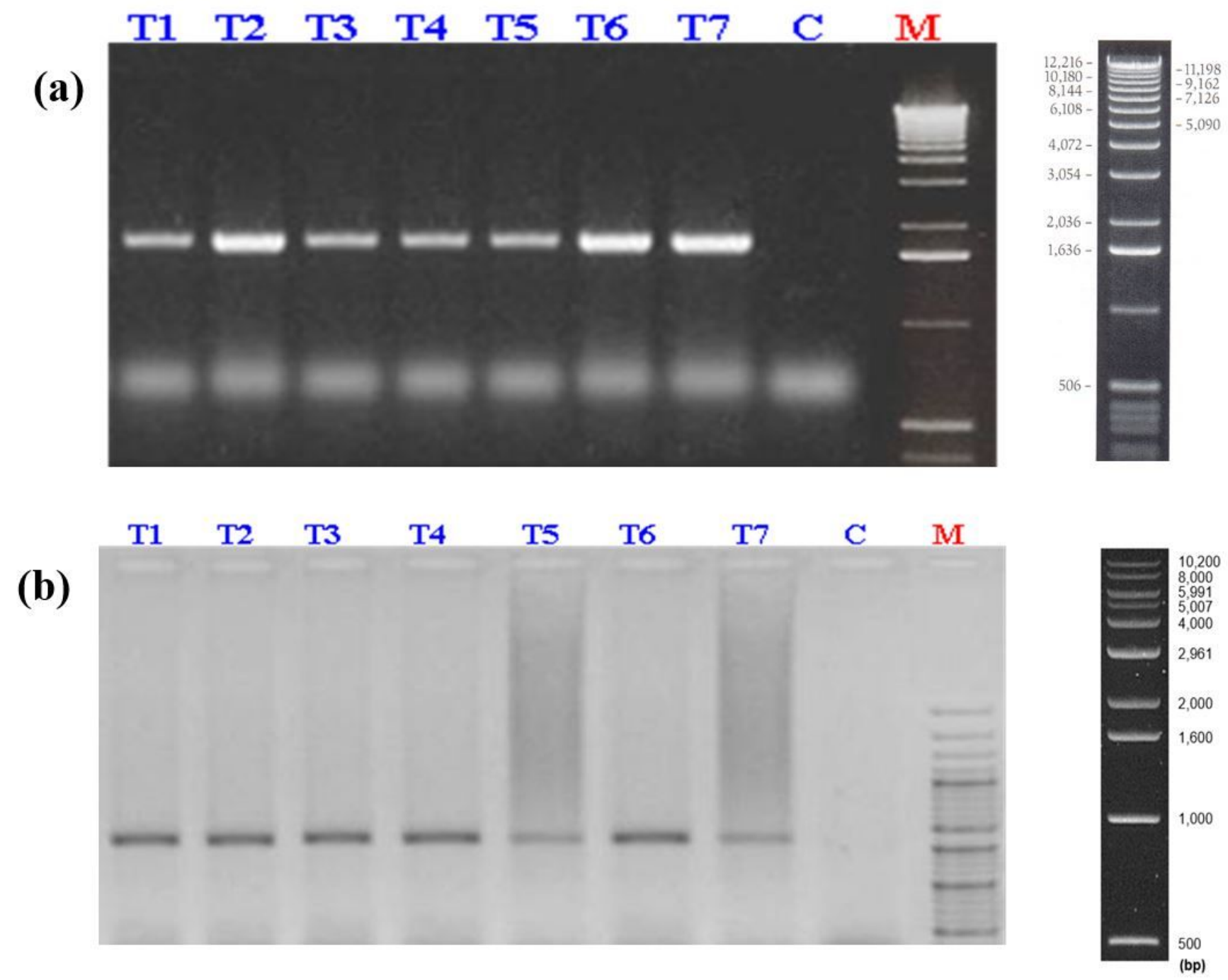

\section{Figure 6}

RT-PCR and Northern blot analysis of transgenic peach (Prunus persica L.) plants. a RT-PCR analysis of seven randomly selected transgenic peach plants of cry $1 \mathrm{Ab}$ showing $1845 \mathrm{bp}$ cry $1 \mathrm{Ab}$ gene transcripts with specific primer. b Northern blot analysis of transgenic peach plants showing RNA blot with 32P dCTP-labelled crylAb probe. Lanes (T1-T7) transgenic peach plants. Lane (C) control (non-transgenic peach plants. Lane (M) Tracklt ${ }^{\mathrm{TM}}$ and AccuLadder ${ }^{\mathrm{TM}} 1 \mathrm{~Kb}$ DNA Ladder). 


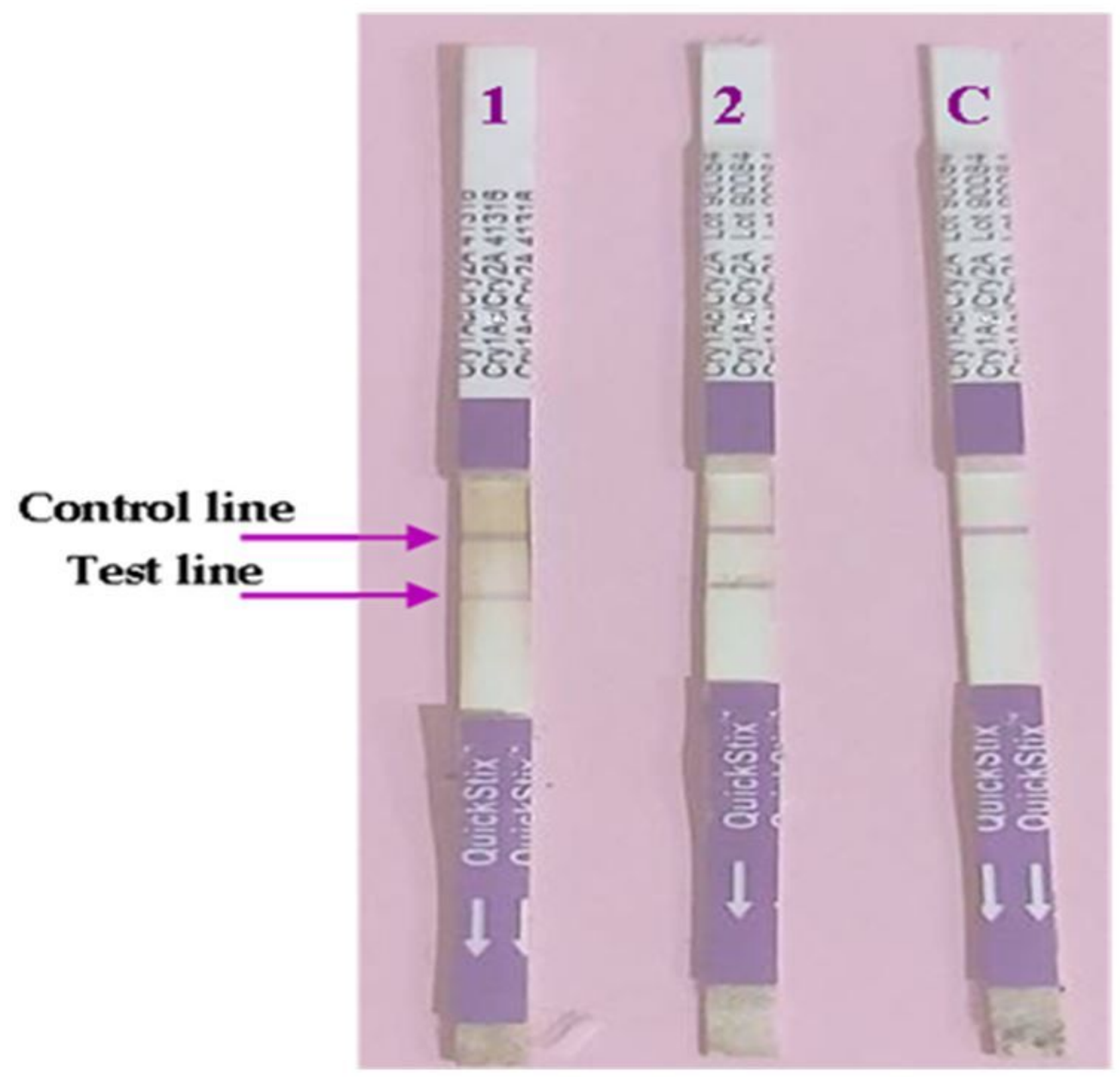

Figure 7

Immunostrip detection of Cry1Ab protein in PCR-positive transgenic peach (Prunus persica L.) plants. Lanes 1 and 2: Transgenic peach plant expressing Cry1Ab protein; Lane c: nontransgenic peach plant. 

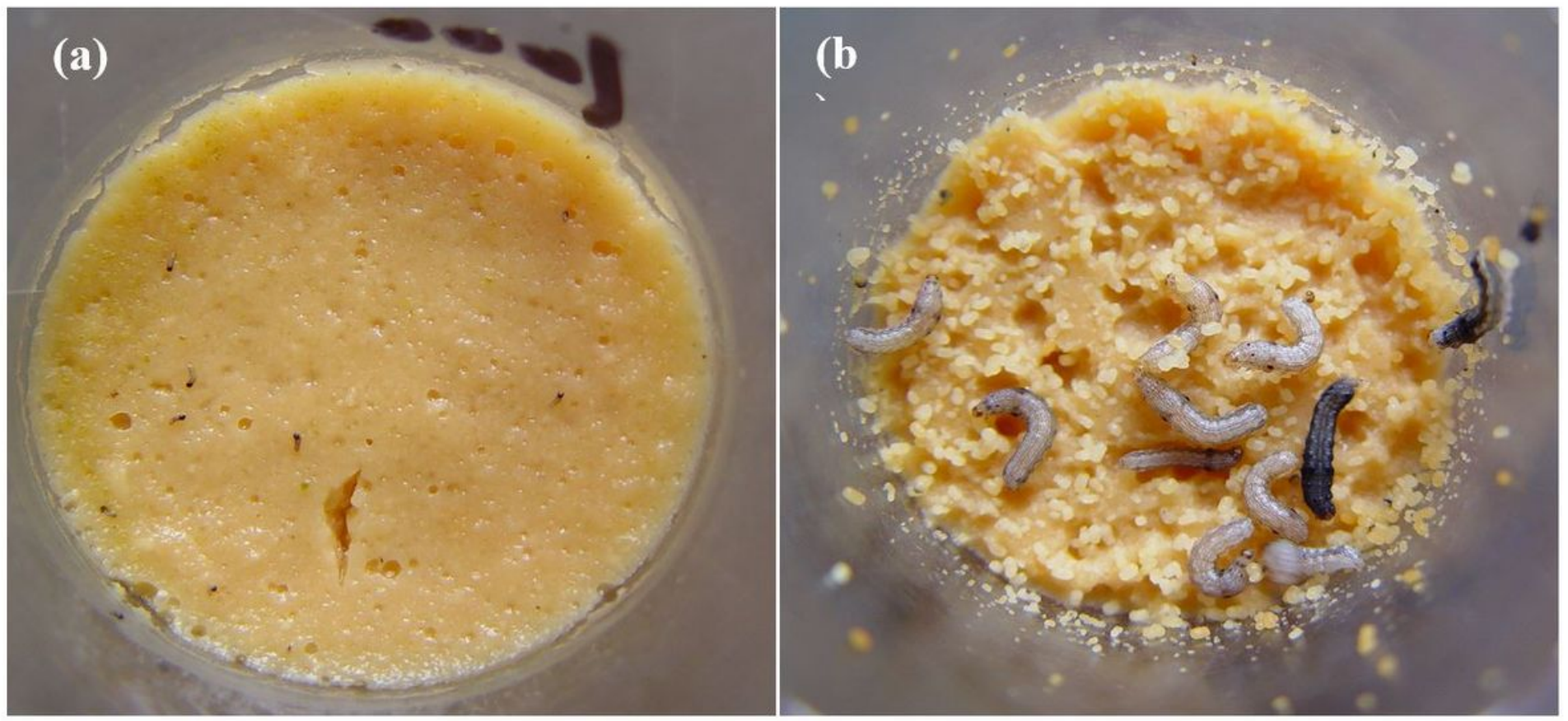

\section{Figure 8}

Effect of toxicity of the transformed peach with cryIAb on Synanthedon exitiosa. a mortality reached $100 \%$ at 1000 ppm of dried transformed peach leaf; b control. 